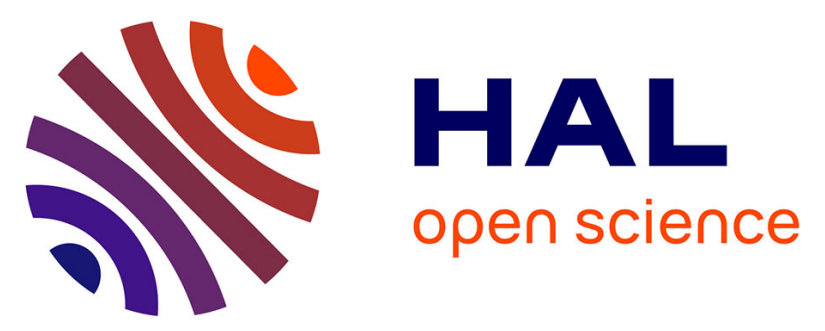

\title{
Central retinal vein occlusion in a sickle cell trait carrier after a cycling race.
}

Mona Hedreville, Philippe Connes, Marc Romana, Guillaume Magnaval, Thierry David, Marie-Dominique Hardy-Dessources, Marie-Sylvaine Belloy, Maryse Etienne-Julan, Olivier Hue

\section{To cite this version:}

Mona Hedreville, Philippe Connes, Marc Romana, Guillaume Magnaval, Thierry David, et al.. Central retinal vein occlusion in a sickle cell trait carrier after a cycling race.: SCT and ophthalmologic complications. Medicine and Science in Sports and Exercise, 2009, 41 (1), pp.14-8. 10.1249/MSS.0b013e31818313d0 . hal-00698572

\section{HAL Id: hal-00698572 https://hal.univ-antilles.fr/hal-00698572}

Submitted on 16 May 2012

HAL is a multi-disciplinary open access archive for the deposit and dissemination of scientific research documents, whether they are published or not. The documents may come from teaching and research institutions in France or abroad, or from public or private research centers.
L'archive ouverte pluridisciplinaire HAL, est destinée au dépôt et à la diffusion de documents scientifiques de niveau recherche, publiés ou non, émanant des établissements d'enseignement et de recherche français ou étrangers, des laboratoires publics ou privés. 


\section{Editorial Manager(tm) for Medicine \& Science in Sports \& Exercise Manuscript Draft}

Manuscript Number: MSSE-D-08-00064R2

Title: Central retinal vein occlusion in a sickle cell trait carrier after a cycling race

Short Title:

Article Type: Clinical Investigation/Case Study

Keywords: hemoglobinopathy; exercise; ophthalmologic complications; red blood cell; coagulation

Corresponding Author: Dr. Philippe Connes, Ph.D.

Corresponding Author's Institution: University of the French West Indies

First Author: Mona Hedreville, M.D.

Order of Authors: Mona Hedreville, M.D.; Philippe Connes, Ph.D.; Marc Romana, Ph.D.; Guillaume Magnaval, M.D.; Thierry David, M.D.; Marie-Dominique Hardy-Dessources, Ph.D.; Marie-Sylvaine Belloy, M.D.; Maryse Etienne-Julan, M.D.; Olivier Hue, Ph.D. 


\section{Case studies}

\section{Central retinal vein occlusion in a sickle cell trait carrier after a cycling race}

Mona Hedreville ${ }^{1,2}$, Philippe Connes ${ }^{1}$, Marc Romana ${ }^{3}$, Guillaume Magnaval ${ }^{4}$, Thierry David ${ }^{4}$, Marie-Dominique Hardy-Dessources ${ }^{3}$, Marie-Sylvaine Belloy ${ }^{3}$, Maryse Etienne-Julan ${ }^{3,5}$, and Olivier Hue ${ }^{1}$.

${ }^{1}$ Laboratory ACTES UPRES-EA 3596, Dpt of Physiology, University of the French West Indies, Campus of Fouillole, Pointe-a-Pitre, Guadeloupe. ${ }^{2}$ Dpt of Cardiology, Academic Hospital, Pointea-Pitre, Guadeloupe. ${ }^{3}$ Inserm, U763, Pointe-a-Pitre, University of the French West Indies, Pointea-Pitre, F-97159 France. ${ }^{4}$ Dpt of Ophtalmology, Academic Hospital, Pointe-a-Pitre, Guadeloupe. ${ }^{5}$ Carribean Sickle Cell Center, Academic Hospital, Pointe-a-Pitre, Guadeloupe.

Corresponding author: Philippe Connes, PhD, Laboratory ACTES UPRES-EA 3596, Dpt of Physiology, University of the French West Indies, Campus of Fouillole, Pointe-a-Pitre, Guadeloupe

Telephone: 5905908348 99,

Fax : 590590830513

Email: pconnes@yahoo.fr,

Running title: SCT and ophthalmologic complications 


\begin{abstract}
A 26-year-old man with sickle cell trait (SCT) suddenly lost visual acuity in the left eye after a cycling race in hot tropical environment. The cause was massive central retinal vein occlusion (CRVO) with hemorrhaging that rapidly worsened to neovascular glaucoma. Although medically treated, the eye is now marked by total retinal detachment. Cardiovascular function assessment shown no electrocardiographic abnormalities, no anomaly in the supra-aortic tree and no evidence of structural heart disease. Although normal coagulation markers values (i.e. activated partial thromboplastin time, prothrombin time, fibrinogen concentration, antithrombin III, factor V, protein $\mathrm{C}$ and $\mathrm{S}$ ) were observed two and a half months after the clinical event, a trans-esophageal echocardiogram performed few hours after the incident revealed the presence of four thrombi in the left atrium suggesting a post exercise hypercoagulable state at that time. Hemorheological measurements at distance of the events demonstrated high red blood cell rigidity at baseline. Therefore, marked blood rheological impairment and activation of the coagulation pathway in response to the heavy and prolonged cycling race could have promoted CRVO in this cyclist carrying SCT. These data suggest that SCT could be considered as a risk factor for significant ocular complications when severe exercise is performed and support the idea that SCT is a contributing factor in blood rheology and vascular dysfunctions.
\end{abstract}

\footnotetext{
Key words: hemoglobinopathy, exercise, ophthalmologic complications, red blood cell, coagulation
} 


\section{Introduction}

Paragraph 1: The heterozygous form of sickle cell anemia (sickle cell trait; SCT) is usually considered as a benign disorder by ophthalmologists, as compared with other forms of sickle cell disease known to be associated with ocular complications (38). We report the first case of CRVO (central retinal vein occlusion) coincident with prolonged and intense exercise that rapidly worsened to neovascular glaucoma and painful blindness, in a young athlete with SCT. Since SCT carriers are often marked by coagulation activity imbalance (36), blood rheological disorders $(28,35)$ and abnormalities in vascular adhesion processes $(29,34)$, both at rest and in response to exercise, we propose that blood and vascular dysfunctions might have contributed to the occurrence of this adverse event.

\section{Case report}

Paragraph 2: A previously healthy 26-year-old Afro-Caribbean male cyclist was admitted to the Ophthalmology Department of the University Hospital of Pointe-à-Pitre the day after a prolonged and intense cycling race in Guadeloupe, a French West Indies island. The competition consisted of 138 kilometers in mountainous terrain and high ambient temperature $\left(35^{\circ} \mathrm{C}\right)$ with $60 \%$ of humidity. The patient felt himself particularly thirsty all along the race. At hospital admission, he presented a sudden loss of visual acuity (VA) of the left eye (6/20). VA of the right eye was normal (20/20). Intraocular pressure (IOP) was normal in both eyes (14 mmHg). Ophthalmoscopy and fluorescein angiography of the left eye documented CRVO with massive retinal hemorrhage (Figure 1). The clinical interview revealed that 1) the patient had already experienced a loss of visual acuity of his left eye two months earlier with spontaneous recovery within two days and 2) 
Paragraph 3: The patient returned one month later to the Department of Ophthalmology for headache, nausea and vomiting, blindness and eye pain in the left eye. The interview revealed that the patient had been doing heavy weight lifting, such as 3-5 maximal repetition method, when these medical signs suddenly appeared. Biomicroscopic exam demonstrated important iris rubeosis and neovascular glaucoma with corneal edema. The neovascular glaucoma was confirmed by gonioscopy. The patient was immediately hospitalized and hypotonic medication was given intravenously (acetazolamide, Diamox ${ }^{\circledR}$ ) as well as locally (timolol maleate, Ophtim ${ }^{\circledR}$ ), which decreased IOP to $20 \mathrm{mmHg}$. A complement of panretinal photocoagulation was performed in 
emergency as soon as the corneal edema was sufficiently reduced. Despite anticoagulation medication, a new trans-esophageal echocardiogram performed three days later revealed two remaining thrombi in the left atrium suggesting that blood coagulation disturbances were still persistent.

Paragraph 4: Two weeks later, the IOP was still high $(>21 \mathrm{mmHg})$ and the patient complained of eye pain. Cryotherapy was performed on both the ciliary body and retina. One month later, assessment of blood rheology by viscometric method $(10,28)$ demonstrated high red blood cell (RBC) rigidity (Table 2). Blood coagulation parameters (activated partial thromboplastin time, prothrombin time and antithrombin III) were also successfully measured and showed normal values (Table 2).

Paragraph 5: The eye pain disappeared at this time, and the patient has since been chronically medicated with rimexolone (Vexol $\left.{ }^{\circledR}\right)$, dorzolamide (Trusopt $\left.{ }^{\circledR}\right)$, brimonidine tartrate (Alphagan $\AA$ ) and latanoprost (Xalatan $\left.{ }^{\circledR}\right)$ to stabilize the IOP. Medication for platelet anti-aggregation was also prescribed for the patient and exercise is not currently recommended. The patient is followed by the Department of Ophthalmology and the Department of Cardiology every two months to monitor IOP and cardiovascular function. The IOP is now stabilized $(12 \mathrm{mmHg})$ but the left eye is marked by total retinal detachment and very low visual acuity, which is limited to weak luminous perception.

Paragraph 6: Informed consent was obtained from the patient and DNA studies were conduced. Briefly, DNA from blood sample was extracted using standard procedure and detection of the prothrombin A 20210, methyltetrahydrofolate reductase T 677 and factor V Leiden alleles were performed as previously described $(15,30,31)$. DNA analysis revealed that the patient did not carry any of these genetic risk factor for retinal vascular occlusion and thrombotic event (6). 


\section{Discussion}

Paragraph 7: We report the first identified case of CRVO associated with prolonged and intense exercise in a SCT carrier with no past history of treatment for ocular complication or other disease. The patient was well trained in endurance cycle and performed 3 cyclists outing per week ( 2 short ones of $60-80 \mathrm{~km}$ and a longer one of more than $100 \mathrm{~km}$ ). In addition, he practiced weight lifting twice a week to complete his training regimen. The situation rapidly deteriorated to neovascular glaucoma and blindness of the eye. Several studies have reported ocular complications in SCT but these complications have usually been described as the consequence of traumatic hyphema $(19,27,38)$. Ophthalmologists therefore consider SCT as a benign condition compared with SS or SC hemoglobinopathy (38). However, this issue is still debated since several reports suggest that SCT could be viewed as a potentially dangerous disorder $(2,37)$, particularly in response to prolonged and intense exercise $(7,12,20,21,23,24,37)$.

Paragraph 8: Interestingly, impaired blood rheology was suggested to be a risk factor for CRVO (25). Gaudard et al. (17) recently demonstrated that hemorheological disturbances are likely to be involved in CRVO. SCT carriers usually have impaired RBC deformability in basal conditions (28), as confirmed by the high RBC rigidity found in the present study. Unfortunately, it was not possible to assess $\mathrm{RBC}$ rigidity closer to the ocular incident (i.e., the day after the cycling race). Exercise is known to further impair blood rheology in SCT carriers because of the increased sickling of erythrocytes, particularly in hot environment (4), and we recently demonstrated that RBC deformability is further impaired 24 hours after strenuous exercise (35). Therefore, it is conceivable that $\mathrm{RBC}$ deformability was also impaired the day after the cycling race and that such abnormality would have been favorable to the occurrence of CRVO. Moreover, the patient 
reported that, despite its efforts to drink water, he felt particularly thirsty during and after the race. Sherry (33) hypothesized that dehydration might contribute to the development of sickling and that SCT carriers might be naturally more predisposed to dehydration due to their inability to concentrate their urine when deprived of water (33). This defect might make SCT carriers less able to conserve water than non-carriers and could have played a role in the occurrence of CRVO. Indeed, higher amount of water intake with appropriate amount of electrolytes (notably sodium) (32) may be required for exercising SCT carriers in comparison with control subjects.

Paragraph 9: Abnormal coagulation activities are also among the several risk factors associated with CVRO (16) The role of hemostasis-fibrinolysis balance in CRVO is supported by the recent results of Ghazi et al. (18), who demonstrated that intravitreal tissue plasminogen activator injection may have a beneficial role in the management of CRVO. Westerman et al. (36) reported elevated d-dimers, thrombin-antithrombin complexes and prothrombin fragments 1.2 in SCT carriers at rest, suggesting that they may be prone to a hypercoagulable state in resting conditions (36). In addition Austin et al. (3) recently provided strong evidences of higher risk to develop venous thromboembolism (odds ratio: 1.8) and pulmonary embolism (odds ratio: 3.9) among African Americans with SCT than in non SCT carriers, in agreement with the reported disequilibrium between coagulation and fibrinolytic activities in SCT carriers. Nevertheless, these results contrast with the present finding of no disorder of blood coagulation two and a half months after the incident (Table 2). Our patient did not carry any of the known genetic risk factor for retinal vascular occlusion, namely prothrombin A 20210, methyltetrahydrofolate reductase T 677 and factor V Leiden variants. 
Paragraph 10: Due to technical problems, the markers of coagulation could not be obtained at the time of the incident and it is possible that, had we obtained them, the blood coagulation properties would have been different. The presence of four thrombi in the left atrium after the occurrence of CRVO strongly suggested the hypercoagulable state of the patient when the incident occurred. Prolonged exercise usually causes changes in coagulation activity in healthy persons (14). Mandalaki et al. (26) previously reported a decrease in antithrombin III activity after a marathon. Therefore, the stress caused by the cycling race could have disturbed the balance between hemostasis and fibrinolysis (36), leading to increased risk for CRVO. We recently demonstrated no difference in prothrombin time, activated partial thromboplastin time, antithrombin III activity and yield stress between SCT carriers and a control population, before and after a strenuous cycling exercise test conducted in laboratories condition (11). Although large hemostatic dysregulations in SCT carriers following exercise, such as disseminated intravascular coagulation (22), have already been reported, we did not investigate fibrinolytic activity in that study (11). Therefore, no conclusion regarding the coagulation activity of the patient at the time of the incident is possible.

Paragraph 11: Despite the panretinal photocoagulation and the venotonic and platelet antiaggregating agent treatment, the CRVO rapidly worsened to rubeosis iridis and neovascular glaucoma, which led to a second emergency hospital visit. Interestingly, the signs of ocular complication (blindness, eye pain, headache, nausea and vomiting) appeared immediately after a session of resistance training. Although it may prove difficult to tease out whether it was the intensity or just the type of exercise that contributed to this second incident, resistance training (and particularly heavy weight lifting) is also known to alter blood rheological parameters and blood coagulation $(1,13)$. These alterations could have been involved in the surprising and rapid 
ocular complication observed in our patient. Despite anti coagulation medication, two thrombi were present at that time in the left atrium suggesting, again, disequilibrium of the balance between hemostasis and fibrinolytic activity. Despite clear medical recommendations, the patient did not stop practicing intense physical activities, which illustrates the problem of preventing and managing further exercise related medical complication in a sportsman.

Paragraph 12: Although under multiple medical treatments, the patient unfortunately lost his left eye. The exact reasons for this severe ocular incident are not clearly understood, and the most surprising event was the rapid deterioration of CRVO to neovascular glaucoma. Usually, the occurrence of CRVO (whether induced by exercise or not) in young men is well managed, leading to recovery (17) with minimal visual after effects. However, this was not the case in the present study and the poor outcome for our patient could be related to its SCT carrier status. Indeed, the concomitant occurrence of hypoxia, dehydration and acidosis, conditions occurring during excercice, is favorable to the sickling process (5) and coagulopathy (20). The presence of SCT and the associated hemorheological disorders could have played a role in the complications (i.e., retinal detachment and blindness).

Paragraph 13: Altogether, the data presented in this case study suggest that SCT status could be another genetic risk factor for severe ocular complications, particularly when severe exercise is performed in extreme climatic conditions. While SCT carriers often participate in sports and related training, particular attention to preventing dehydration and starting exercise gradually may be warranted. These recommendations have to be applied to the general population; but we do advocate that physicians and trainers should pay a greater attention to people (trained or untrained) carrying SCT. The recommendation on adequate hydration is particularly important for SCT 
carriers because they are naturally more predisposed to dehydration due to their inability to concentrate their urine when deprived of water (33). This defect might make SCT carriers less able to conserve water than non-carriers. Blood rheological disorders and coagulation imbalance following intense physical exercise such as heavy and prolonged cycling race could promote CRVO in SCT carriers. This report provides data suggesting that SCT could be considered as a risk factor for severe ocular complications when severe exercise is performed. Several forms of clinical complications related to exercise or not, have already been described in SCT carriers and might be related to different blood and vascular dysfunctions $(8,9)$.

Acknowledgments: This work was supported by our academic funding. The results of the present study do not constitute endorsement by ACSM.

Conflict of interest: We state that there is no conflict of interest. 


\section{References}

1. Ahmadizad S, El-Sayed MS. The acute effects of resistance exercise on the main determinants of blood rheology. J Sports Sci. 2005;23:243-9.

2. Ajayi AA. Should the sickle cell trait be reclassified as a disease state? Eur J Intern Med. 2005;16:463.

3. Austin H, Key NS, Benson JM, Lally C, Dowling NF, Whitsett C, et al. Sickle cell trait and the risk of venous thromboembolism among blacks. Blood. 2007;110:908-12.

4. Bergeron MF, Cannon JG, Hall EL, Kutlar A. Erythrocyte sickling during exercise and thermal stress. Clin J Sport Med. 2004;14:354-6.

5. Bookchin RM, Balazs T, Landau LC. Determinants of red cell sickling. Effects of varying $\mathrm{pH}$ and of increasing intracellular hemoglobin concentration by osmotic shrinkage. $J$ Lab Clin Med. 1976;87:597-616.

6. Chak M, Wallace G, Graham E, Stanford M. Thrombophilia: genetic polymorphisms and their association with retinal vascular occlusive disease. Br J Ophthalmol. 2001;85:883-6.

7. Connes P, Hardy-Dessources MD, Hue O. Counterpoint: Sickle cell trait should not be considered asymptomatic and as a benign condition during physical activity. $J$ Appl Physiol. 2007;103:2138-40.

8. Connes P, Hue O, Tripette J, Hardy-Dessources MD. Blood rheology abnormalities and vascular cell adhesions mechanisms in sickle cell trait carriers during exercise. Clin Hemorheol Microcirc. In press.

9. Connes P, Reid H, Hardy-Dessources MD, Morrison E, Hue O. Physiological Responses of Sickle Cell Trait Carriers During Exercise. Sports Med. In press. 
10. Connes P, Sara F, Hardy-Dessources MD, Etienne-Julan M, Hue O. Does Higher Red Blood Cell (RBC) Lactate Transporter Activity Explain Impaired RBC Deformability in Sickle Cell Trait? Jpn J Physiol. 2005;55:385-7.

11. Connes P, Tripette J, Chalabi T, Beltan E, Etienne-Julan M, Chout R, et al. Effects of strenuous exercise on blood coagulation activity in sickle cell trait carriers. Clin Hemorheol Microcirc. 2008;38:13-21.

12. Dincer HE, Raza T. Compartment syndrome and fatal rhabdomyolysis in sickle cell trait. Wmj. 2005; 104:67-71.

13. el-Sayed MS. Fibrinolytic and hemostatic parameter response after resistance exercise. Med Sci Sports Exerc. 1993;25:597-602.

14. el-Sayed MS. Effects of exercise on blood coagulation, fibrinolysis and platelet aggregation. Sports Med. 1996;22:282-98.

15. Frosst P, Blom HJ, Milos R, Goyette P, Sheppard CA, Matthews RG, et al. A candidate genetic risk factor for vascular disease: a common mutation in methylenetetrahydrofolate reductase. Nat Genet. 1995;10:111-3.

16. Fruschelli M, Puccetti L, Bruni F, Auteri A. Coagulative, fibrinolytic and metabolic pattern in patients with central retinal vein occlusion. Ophthalmologica. 2002;216:108-12.

17. Gaudard A, Varlet-Marie E, Monnier JF, Janbon C, Quere I, Bressolle F, et al. Exerciseinduced central retinal vein thrombosis: possible involvement of hemorheological disturbances. A case report. Clin Hemorheol Microcirc. 2002;27:115-22.

18. Ghazi NG, Noureddine B, Haddad RS, Jurdi FA, Bashshur ZF. Intravitreal tissue plasminogen activator in the management of central retinal vein occlusion. Retina. $2003 ; 23: 780-4$ 
19. Goldberg MF. Sickled erythrocytes, hyphema, and secondary glaucoma: I. The diagnosis and treatment of sickled erythrocytes in human hyphemas. Ophthalmic Surg. 1979;10:1731.

20. Jones SR, Binder RA, Donowho EM, Jr. Sudden death in sickle-cell trait. $N$ Engl J Med. 1970;282:323-5.

21. Kark JA, Ward FT. Exercise and hemoglobin S. Semin Hematol. 1994;31:181-225.

22. Koppes GM, Daly JJ, Coltman CA, Jr., Butkus DE. Exertion-induced rhabdomyolysis with acute renal failure and disseminated intravascular coagulation in sickle cell trait. Am J Med. $1977 ; 63: 313-7$.

23. Le Gallais D, Lonsdorfer J, Bogui J, Fattoum S, versus, Connes P, et al. PointCounterpoint: Sickle cell trait should/should not be considered asymptomatic and as a benign condition during physical activity. J Appl Physiol. 2007;In Press.

24. Le Gallais D, Lonsdorfer J, Bogui P, Fattoum S. Point: Sickle cell trait should be considered asymptomatic and as a benign condition during physical activity. $J$ Appl Physiol. 2007;103:2137-8.

25. Lip PL, Blann AD, Jones AF, Lip GY. Abnormalities in haemorheological factors and lipoprotein (a) in retinal vascular occlusion: implications for increased vascular risk. Eye. 1998;12 ( Pt 2):245-51.

26. Mandalaki T, Dessypris A, Louizou C, Panayotopoulou C, Dimitriadou C. Marathon Run III: effects on coagulation, fibrinolysis, platelet aggregation and serum cortisol levels. A 3year study. Thromb Haemost. 1980;43:49-52.

27. Michelson PE, Pfaffenbach D. Retinal arterial occlusion following ocular trauma in youths with sickle-trait hemoglobinopathy. Am J Ophthalmol. 1972;74:494-7. 
28. Monchanin G, Connes P, Wouassi D, Francina A, Djoda B, Banga PE, et al. Hemorheology, sickle cell trait, and alpha-thalassemia in athletes: effects of exercise. Med Sci Sports Exerc. 2005;37:1086-92.

29. Monchanin G, Serpero LD, Connes P, Tripette J, Wouassi D, Bezin L, et al. Effects of a progressive and maximal exercise on plasma levels of adhesion molecules in athletes with sickle cell trait with or without \{alpha\}-thalassemia. J Appl Physiol. 2007;102:169-73.

30. Nowak-Göttl U, Wermes C, Junker R, Koch HG, Schobess R, Fleischhack G, et al. Prospective evaluation of the thrombotic risk in children with acute lymphoblastic leukemia carrying the MTHFR TT 677 genotype, the prothrombin G20210A variant, and further prothrombotic risk factors. Blood. 1999;93:1595-9.

31. Poort SR, Rosendaal FR, Reitsma PH, Bertina RM. A common genetic variation in the 3'untranslated of the prothrombin gene is associated with elevated plasma prothrombin levels and an increase in venous thrombosis. Blood. 1996;88:3698-703.

32. Sawka MN, Burke LM, Eichner ER, Maughan RJ, Montain SJ, Stachenfeld NS. American College of Sports Medicine position stand. Exercise and fluid replacement. Med Sci Sports Exerc. 2007;39:377-90.

33. Sherry P. Sickle cell trait and rhabdomyolysis: case report and review of the literature. Mil Med. 1990;155:59-61.

34. Tripette J, Connes P, Hedreville M, Etienne-Julan M, Marlin L, Hue O, et al. Patterns of exercise related inflammatory response in sickle cell trait carriers. Brit J Sports Med. In press.

35. Tripette J, Hardy-Dessources MD, Sara F, Montout-Hedreville M, Saint-Martin C, Hue O, et al. Does Repeated and Heavy Exercise Impair Blood Rheology in Carriers of Sickle Cell Trait? Clin J Sport Med. 2007;17:465-70. 
36. Westerman MP, Green D, Gilman-Sachs A, Beaman K, Freels S, Boggio L, et al. Coagulation changes in individuals with sickle cell trait. Am J Hematol. 2002;69:89-94.

37. Wirthwein DP, Spotswood SD, Barnard JJ, Prahlow JA. Death due to microvascular occlusion in sickle-cell trait following physical exertion. J Forensic Sci. 2001;46:399-401.

38. Wolf A, Shalem M, Horowitz J, Geyer O. Retinal vascular occlusion following traumatic hyphema and glaucoma, as a presenting sign of sickle cell trait. Isr Med Assoc J. 2005;7:476-7. 


\section{Figure legends:}

Figure 1: Hemorrhagic form of an inferior-predominating central retinal vein occlusion. To be noted: the papillary stasis oedema, the extreme dilation and twisting of the veins and the large retinal bleeding areas are signs of severe ischemia. 
$\underline{\text { Responses to the reviewers and list of changes }}$

Med Sci Sports Exerc - MSSE-D-08-00064R1

Central retinal vein occlusion in a sickle cell trait carrier after a cycling race

Mona Hedreville, Philippe Connes, Marc Romana, Guillaume Magnaval, Thierry David, Marie-Dominique Hardy-Dessources, Marie-Sylvaine Belloy, Maryse Etienne-Julan, and Olivier Hue.

We would like to thank the reviewers for their critical appraisals and interesting comments on our manuscript. We have attempted to fully answer all the questions and to respond with more details where required. The changes introduced in the reviewed manuscript are in red to make the reviewing process easier.

Reviewer 1:

No further comments

\section{Reviewer 2:}

First, the authors would like to thank the reviewer for her/his additional comments.

\section{General comments}

1) Regarding the "centered" or "middle dot" ("•") character, perhaps this was converted to a "period" in the submission process, and copyediting will take care of this. In any case, the units of measure in the tables should be in a format such as "g·l-1 (superscript)". A few additional specific changes need to be made (indicated below). We apologize for this mistake. We made the corrections everywhere in the tables.

\section{Specific comments}

2) Abstract Line 24: It would be cleaner to change to read "observed two and a half months after the clinical event."

We made the corrections.

\section{3) Abstract Line 38: Change to read "These data suggest that SCT."}

We made the changes. 
4) Abstract Line 41: Change to read "factor for significant ocular ."

As requested, we replaced "severe" by "significant".

5) Abstract Line 43: Do the authors mean to say "SCT is a contributing factor in blood rheology and vascular dysfunctions"?

Yes, the reviewer is correct. We replaced our sentence by the sentence proposed by the reviewer.

6) Page 3 Line 14: CRVO needs to be defined here.

Line 24: Change to "we propose."

Line 26: Change to "might have contributed."

Line 36-44: Again, it is a little confusing having the phrase "practicing cycling" and then mention a "race" and "competition" (Was this practice or competition?). Do the authors simply mean to say "Afro-Caribbean male cyclist was admitted."?

As requested, we made all the modifications.

7) Page 7 Line 16: Use the most current position statement on exercise and fluid replacement which replaces the 1996 statement cited here (Sawka et al. Med Sci Sports Exerc. 2007).

We agree with the reviewer and we inserted the proposed reference.

8) Page 9 Line 50-3: Change to read "general population; but we also advocate." We made the corrections.

9) Table 2 - Use "incident" vs. "accident" in the legend.

We made the changes. 
Table 1: Hematological, inflammatory, biochemical parameters measured the day after the cycling race (day of the initial accident)

\begin{tabular}{|c|c|c|}
\hline Parameter & Patient value & Normal value \\
\hline Red blood cells $\left(10^{12} \cdot 1^{-1}\right)$ & 4.9 & $4.5-6.5$ \\
\hline Hematocrit (\%) & 44.1 & $40-54$ \\
\hline Hemoglobin $\left(\mathrm{g} \cdot \mathrm{dl}^{-1}\right)$ & 15.4 & $13.0-17.0$ \\
\hline Mean corpuscular volume (fl) & 89.5 & $80-100$ \\
\hline $\begin{array}{c}\text { Mean corpuscular hemoglobin } \\
\text { concentration }(\mathrm{pg})\end{array}$ & 31.2 & $27-32$ \\
\hline Hemoglobin A (\%) & 50.8 & \\
\hline Hemoglobin S (\%) & 38.9 & \\
\hline Hemoglobin F (\%) & 1.2 & \\
\hline Hemoglobin A2 (\%) & 3.5 & \\
\hline Platelets $\left(10^{9} \cdot 1^{-1}\right)$ & 183 & $150-500$ \\
\hline Sedimentation rate $\left(\mathrm{mm} \cdot \mathrm{h}^{-1}\right)$ & 5 & $<15$ \\
\hline Leukocytes $\left(10^{9} \cdot 1^{-1}\right)$ & 4.4 & $4.0-10.0$ \\
\hline Polynuclear neutrophils $\left(10^{9} \cdot 1^{-1}\right)$ & 1.7 & $1.8-7.5$ \\
\hline Polynuclear eosinophils $\left(10^{9} \cdot 1^{-1}\right)$ & 0.05 & $0.04-0.8$ \\
\hline Polynuclear basophils $\left(10^{9} \cdot 1^{-1}\right)$ & 0.02 & $0.00-0.2$ \\
\hline Lymphocytes $\left(10^{9} \cdot 1^{-1}\right)$ & 2.4 & $1.0-4.0$ \\
\hline Monocytes $\left(10^{9} \cdot 1^{-1}\right)$ & 0.25 & $0.2-1.00$ \\
\hline C-reactive protein $\left(\mathrm{mg} \cdot \mathrm{l}^{-1}\right)$ & 3.1 & $<5$ \\
\hline $\mathrm{C} 3$ fraction of complement $\left(\mathrm{g} \cdot \mathrm{l}^{-1}\right)$ & 1.11 & $0.75-1.4$ \\
\hline $\mathrm{C} 4$ fraction of complement $\left(\mathrm{g} \cdot \mathrm{l}^{-1}\right)$ & 0.14 & $0.1-0.34$ \\
\hline $\begin{array}{l}\text { Anticardiolipin antibody Ig G } \\
\qquad\left(\text { GPL units } \cdot \mathrm{ml}^{-1}\right)\end{array}$ & 3 & $<11$ \\
\hline $\begin{array}{l}\text { Anticardiolipin antibody } \operatorname{Ig} \mathrm{M} \\
\text { (MPL units } \cdot \mathrm{ml}^{-1} \text { ) }\end{array}$ & 10 & $<11$ \\
\hline
\end{tabular}

No parameter was outside the reference range 
Table 2: Red blood cell rigidity, blood coagulation markers measured two and a half months after the initial incident and one month after the end of anti-coagulation treatment.

\begin{tabular}{|c|c|c|}
\hline Parameter & Patient value & Normal value \\
\hline Red blood cell rigidity (shear rate of $\left.225 \mathrm{~s}^{-1}\right)^{*}$ & 0.88 & $<0.85$ \\
\hline Activated partial thromboplastin time (s) & 31 & $<1.52$ \\
\hline Ratio (healthy subject/patient) & 1.10 & $70-100$ \\
\hline Prothrombin time (\%) & 90 & $2.00-4.50$ \\
\hline Fibrinogen (g-1 $\left.{ }^{-1}\right)$ & 2.50 & $70-120$ \\
\hline Antithrombin III (\%) & 94 & $70-120$ \\
\hline Factor V (\%) & 104 & $70-130$ \\
\hline Protein C (\%) & 70 & $65-140$ \\
\hline Protein S (\%) & 68 & $>0.70$ \\
\hline Resistance to activated protein C (normalized ratio) & 1.00 & $<5.00$ \\
\hline C-reactive protein (mg· $\mathrm{l}^{-1}$ ) & 3.19 & \\
\hline
\end{tabular}

* Except for red blood cell rigidity, no parameter was outside the reference range 


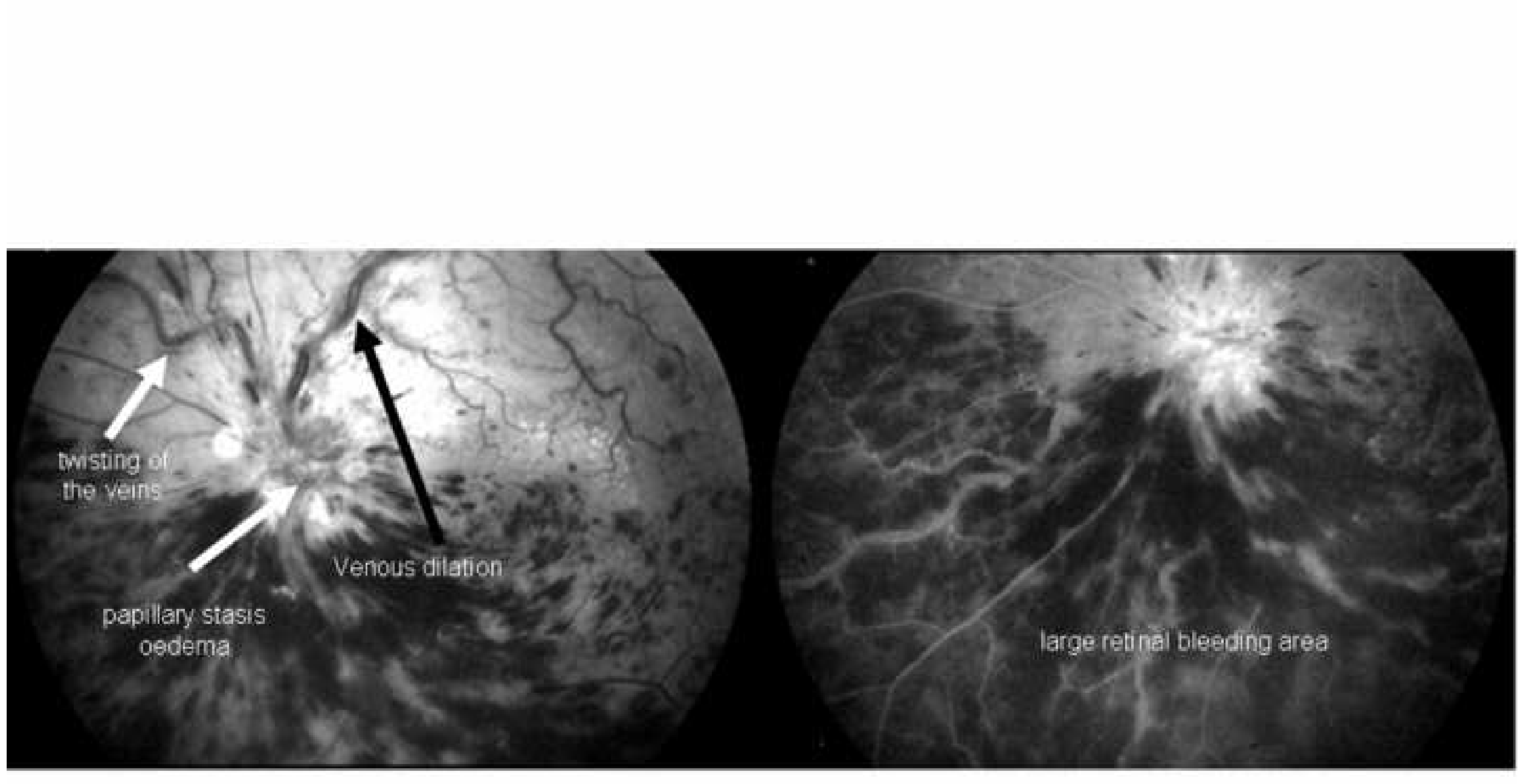

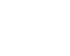 \\ here to download high resolution image
}
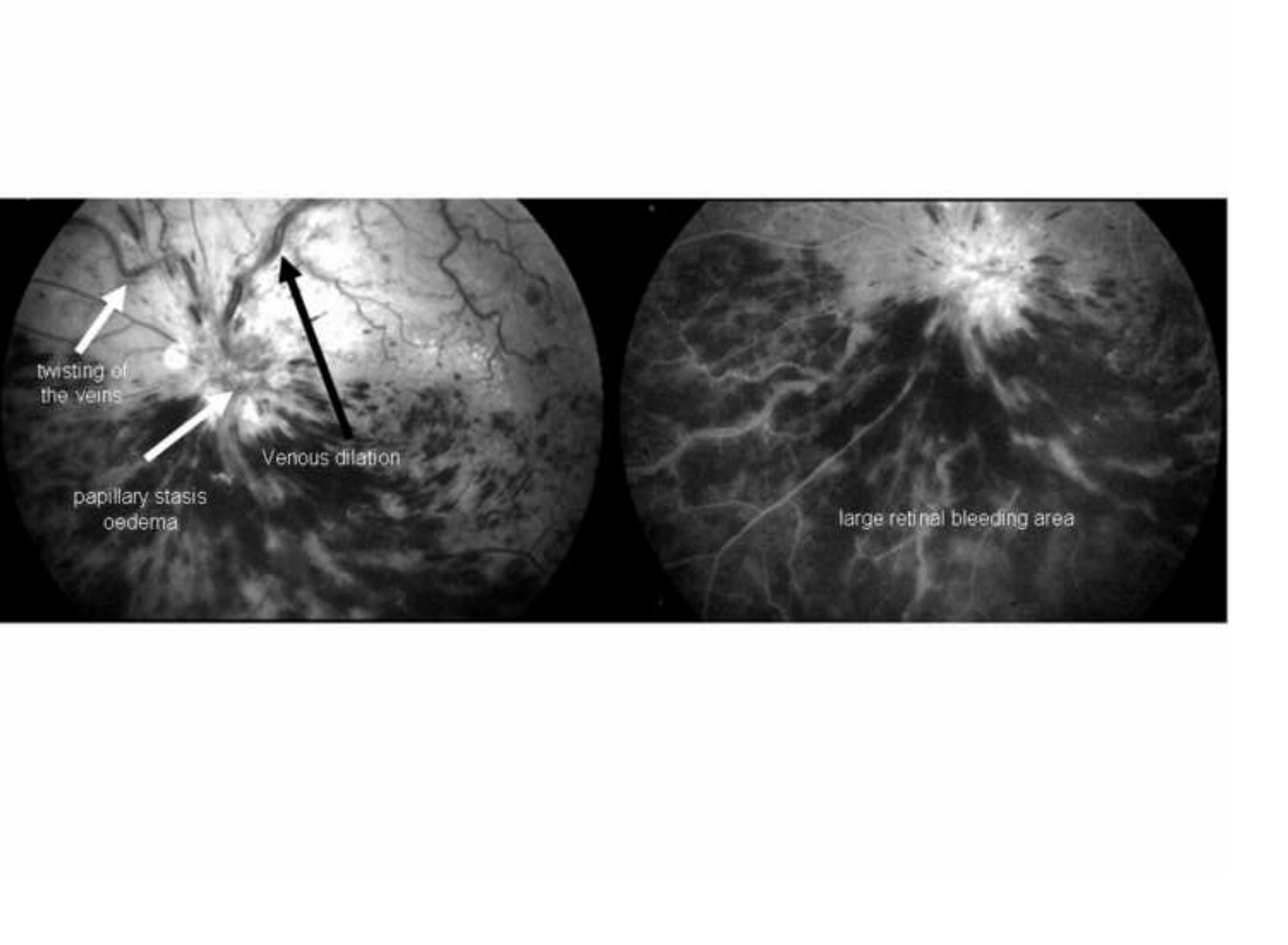